\title{
Religious Migration: the History of Missionary Work in Siberia
}

\author{
Nadeghda Ia. Artamonova*, Valentina N. Asochakova* \\ and Svetlana S. Chistanova \\ Katanov State University of Khakassia \\ 90 Lenin Str., Abakan, 655017, Khakassia
}

Received 27.04.2018, received in revised form 14.08.2018, accepted 16.08.2018

The article analyses missionary work as a form of religious migration. The settlement of Siberia by Russians was the most important geopolitical and economic task of the Russian government. In this process Christianization of the native population of Siberia was very important. From the 17th to the 20th century the state policy towards Siberia was changing, as well as the forms and methods of dissemination of Orthodoxy among the native Siberian people. The article describes in details six stages in the state policy of Christianization, from the first acquaintance with the Orthodoxy to the transition to the policy of Russification.

Each Siberian region in Russia has passed several stages: actual annexation, gradual incorporation, assimilation. These processes had regional features and occurred asynchronously. Within two centuries of missionaries' activity in Siberia, violent Christianization methods have been replaced by tactics of tolerance and enlightenment while preserving the monopoly of the Russian Orthodox Church. Unfortunately, the modern concept of the activity of the diocesan mission department shows that the Russian Orthodox Church has not taken into account the historical experience of the missionaries of the past.

Keywords: missionary work, religious migration, settlement of Siberia, Orthodoxy, Christianization.

The study was carried out with the financial support of the RFBR and the Republic of Khakassia within the framework of the scientific project No. 18-49-190002.

Research area: history.

Citation: Artamonova, N.Ia., Asochakova, V.N., Chistanova S.S. (2018). Religious migration: the нistory of missionary work in Siberia. J. Sib. Fed. Univ. Humanit. soc. sci., 11(8), 11881210. DOI: 10.17516/1997-1370-0301.

(C) Siberian Federal University. All rights reserved

* Corresponding author E-mail address: kipp@khsu.ru; asocvn@mail.ru 


\section{Introduction}

One of the forms of migration is religious migration that traditionally means a change of residence due to pressure from representatives of a more widespread religion or a pilgrimage. The problems of religious migration are in the zone of constant academic discussion. The most relevant studies include the works of R.W. Stump (1984), M. Maliepaard, M. Lubbers (2013), S. Allievi (2014), A. Bohman, M. Hjerm, (2014), P.B.N. Bloom, G. Arikan, M. Courtemanche (2015), M. Sanchez, F.R. Dillon, M. Concha, M. De La Rosa (2015), J. Fox, Y. Akbaba (2015), R.K. Brown, R.E. Brown (2017) and many other researchers. These authors consider religious migration in a regional context. However, such a region as Siberia is still insufficiently explored in the context of the analysis of specific forms of religious migration, including religious missionary work.

The article considers such a type of religious migration as missionary work, the missionaries changed their place of residence (usually voluntarily and temporarily) to create favourable living conditions for immigrants in Siberia, contributing to the development of individual regions, the missionaries' activity helped to acquire Siberia's modern borders and look. Increased attention to the missionary activity of the Orthodox Church is also associated with the revival of the missionary activity of the church. At the Bishops' Council of the Russian Orthodox Church (ROC) in 1994 it was one of the main issues, in October, 1995 the concept of the revival of the Orthodox mission was approved, and in December, 1995 the Missionary Department of the Moscow Patriarchate was established. From 1995 to 2018, 5 All-Church congresses of diocesan missionaries have been held. The Belgorod Orthodox Theological Seminary with a missionary orientation began its work at the department, the monthly magazine "Missionary Review" is being published. In May 2018, the concept of the diocesan missionary department's activity was approved. Diocesan bishops and diocesan missionary departments are recommended to act in accordance with this concept. The authors of the article suggest turning to the historical experience of the ROC revealing the stages, methods, ways, and, most importantly, considering the results of missionary work in Siberia. Perhaps, the offered information and the analysed experience can also help modern organizers of missionary activity.

There were three forms of organization of Christianization of the indigenous peoples in Siberia: the first form is a purposeful state policy through the prestimony churches; the second form is departmental, through the secular clergy by means of 
preaching or forcible conversion of "non-Russian aliens"; the third form - through direct contacts with the Orthodox in the process of joint economic activity.

In the pre-revolutionary period, the missionary activity of the Russian Orthodox Church was carried out in three directions: an external mission, an internal mission, a foreign mission. The external mission included work among the "non-Orthodox" both inside and outside the state; the internal mission struggled against the Old Believers and sectarians, its main task was "to protect Orthodoxy and all the people from religious delusions"; the foreign mission operated outside the state. Thus, the external mission of the Russian Orthodox Church is of special interest to us.

\section{Discussion}

In order to understand the nature of the external missionary activity of the ROC, we will analyse the methods used to convert non-believers to Orthodoxy. For the purposes of discussion let us divide them into violent and non-violent ones. The first group of methods may include the destruction of idols, fines for non-observance of Orthodox rites, mass baptisms accompanied by violence. The second group of methods include the means of religious persuasion, material incentives - monetary rewards, exemption from duties, distribution of things, objects of the Orthodox cult; spiritual missions, schools, translation of religious texts into national languages.

In Russian historiography, there is also a tradition of dividing methods into religious and non-religious, while violence is considered as an independent method. Violence is present in all methods and is manifested in baptism with the help of punishment, in the destruction of religious objects of traditional beliefs and so on. The religious methods include preaching that contributed to the adherence of new followers, liturgical activities that helped shape and develop religious activities, maintaining community of religion used only for internal mission (Nikonov, 1989: 7-8).

The effectiveness of missionary activity could depend on the most unexpected factors. For example, geographical conditions of the "field of missionary activity" were of great importance. These are the territories where the mission of the church is carried out. The areas with natural barriers, for example, mountain or taiga areas were the most difficult. The territories' remoteness from the places of residence of Russians, from diocesan centres and churches also had a negative impact on the success of missionary activity. Sometimes the life and work of a missionary depended on seasonal climatic conditions that made it difficult to travel (for example, floods or river overflow). 
The missionary activity has several stages, depending on the forms and methods of baptism, the main task of which was attracting new supporters of Orthodoxy, strengthening loyalty to the chosen religion, avoiding retreat from Orthodoxy; expanding religious knowledge of believers. To accomplish these tasks, various means were used, such as preaching, catechism, extra-liturgical discussions; it was even possible to study other religious teachings and their criticism from the point of view of Orthodox dogmatism. In fact, liturgical activity that was designed to form and develop the skills of religious activities controlled religious behaviour. By this activity we mean liturgical services, religious processions and other religious activities. Non-religious methods of Christianization accessible to missionaries include enlightenment, charity and migration, which were of non-directional nature.

The first Christians from representatives of the indigenous ethnic groups appeared beyond the Urals after the Russians moved to these territories. The term "newly baptized" was used to refer to such "new" Orthodox Christians. It was used for the Orthodox "Yasak foreigners", thereby separating them from both Russian subjects and from the autochthons of Siberia. To refer to the indigenous peoples living in Siberia until the first quarter of the $18^{\text {th }}$ century, the term "foreigners" was officially used in the system of Russian citizenship. This was due to the fact that Orthodoxy was the defining criterion of allegiance to the Russian Tsar. People's attitude to the state power was determined by the following terms - "peaceful", "non-peaceful", "Yasak", "nonYasak". Ethnicity or geographical location was determined by the terms "brotherly", "Krasnoyarsk", "Yakut", etc. In the $18^{\text {th }}$ - early $19^{\text {th }}$ centuries, the term "Yasak people of other faiths" occurred, which meant Russian nationality and confessional otherness. Since the mid-20's of the $19^{\text {th }}$ century the term "foreigner" has come into use, emphasizing different ethnicity (Kovaliashkina, 2005: 50).

The decree of Boris Godunov issued in 1600, according to which it was ordered "to build churches for newly baptized foreigners" (Mavliutova, 2001: 31), initiated the baptism of the indigenous peoples of Siberia. In 1620, an independent diocese was established in Siberia, and on May 30, 1621, the first Archbishop Kipriian Starorusennikov arrived in Tobolsk. But throughout the entire $17^{\text {th }}$ century, there were no legal grounds for the activities of the ROC, so baptism was of an occasional, episodic nature.

In the $17^{\text {th }}$ century, the religious policy was aimed at addressing issues related to the fiscal and geopolitical interests of the Russian government; Christianization was not in the first place. Only in the $18^{\text {th }}$ century, Christianization acquired a character of 
the state policy, the methods of which had changed throughout the century. At the end of the $17^{\text {th }}$ century, Peter the Great issued a decree that forbade the baptism carried out by anyone except for the priests, and it was this decree that initiated establishment of missionary activities in the system. At that time, Russia's positions in Siberia were strengthened, and the tasks of ideological consolidation of political successes in joining the region came to the fore. And in 1700, after the decree on the removal of Metropolitan Ignatius and the appointment of Philotheus, a purposeful baptism of the Siberian peoples began. The decree on mass baptism of the Khanty and Mansi regulated the methods of baptism. The policy towards "foreigners" was the continuation of Peter the Great's reforms, which included: the desire to encompass all aspects of life with rigid regulation, pragmatism, the idea of universal good and tough methods of putting these ideas into practice. The Tsar's personal decree ordered "to be baptized at the age of six months..., and if they do not receive baptism, then estates and ancestral lands together with the peasants will be left to the Great Sovereign." The pagan temples were ordered to burn down, and to build chapels and churches in their places, all residents were to be baptized "from baby to adult ${ }^{1}$." Pragmatism manifested itself in tax benefits for the newly baptized; some were awarded land, released from criminal punishments, including death penalty for murder and grave crimes. The decree of 1720 freed the newly baptized from paying the Yasak for three years.

Great tribute to the practical implementation of the state provisions in the religious policy in Siberia and to the formation of missionary activity unquestionably belongs to Philothea Leszczynski. He was appointed by the Metropolitan of Siberia and Tobolsk on June 18, 1700. His work helped to realize a model of Christianization of the indigenous peoples that is characteristic of the spiritual authorities. Leszczynski carried out baptism in order to "...gradually bring the blind and obdurate inhabitants of Siberia and Mongolia to the knowledge of true God ${ }^{2}$." Not only he baptized himself, but also sent Orthodox missions headed by Archimandrite Marinin to Kamchatka (1705), to the Berezovsky Ostyaks (1707), Mongolia. In 1712, Philothea left for the Tyumen monastery because of illness, but in 1715 he returned to the metropolitan chair, having replaced Ioannes Maksimovich. During this time, he undertook missionary trips along the Berezovsky region, down the Irtysh and the Ob', as well as to the Pelymsky Region, Surgutsky, Narymsky, Ketsky, Tomsky, and Yeniseisky. The church historians tend to 
exaggerate the results of his missionary work noting that he baptized 40,000 Siberian "pagans.".

The legal basis for the policy of Christianization was a series of decrees of 1720 that ordered the Siberian Governor Prince A.M. Cherkassky "to give personal freedom to newly-baptized serf people from Siberia and declare to Russian people the prohibition to turn baptized non-Russians into servility and put bondage on them ${ }^{2}$." To the request of the governor "whether to give out salary to the priests who were put in the church for foreigners, whether to build churches at the expense of the treasury for foreigners turning to Orthodoxy, whether to reward foreigners turning to Orthodoxy", the Senate ruled: "To pay salaries to priests and junior deacons of the existing churches, and henceforth of the newly built ones, and to reward the foreigners who will accept the Christian faith" (Andrievich, 1886: 104). At the same time, the newly-baptized were released from poll taxes and state duties for three years; it was recommended that the metropolitans would receive one thousand roubles per year from the funds of the Collegium of State Expenses and unassessed taxes for building churches and encouraging the newly-baptized ${ }^{3}$.

The church constitution forbade priests to take payment for baptism, wedding ceremony, burial ${ }^{4}$ from newly-baptized people, and the decree of 1722 exempted the baptized people from the recruiting duty ${ }^{5}$. The decree of 1726 freed all those who accepted Orthodoxy "...in all the districts through Narym, along the Chulym and beyond Tomsk" from any form of dependence under the threat of death penalty. The decree ordered, "notwithstanding the serfdom, to give them passports, so that they are no longer enslaved ${ }^{6}$." In the same year, the newly-baptized were excluded from the census, and according to the decree of September 30, 1726 they were returned the lands that had been decommissioned by the decree of $1713^{7}$.

Thus, in the first quarter of the $18^{\text {th }}$ century the legal, preferential status of the newly-baptized was defined. But in reality, the newly-baptized received privileges rarely or did not receive them at all. Here, bureaucracy that is characteristic of the activity of the highest state apparatus of Russia of the period of absolutism manifested

Tobolsk Eparchy (1892). Omsk, Part 2, section 1: Archpastors of the Tobolsk diocese, p. 51-55.

Complete collection of laws of the Russian Empire (1830). In 45 volumes, Saint Petersburg, 6, No. 3636.

Ibid., No. 3637.

Complete collection of laws of the Russian Empire (1830). In 45 volumes, Saint Petersburg, 6, No. 3718.

Ibid., No. 4123.

State Budgetary Institution of the Tyumen Region "State Archives in Tobolsk": F. 530: Tobolsk Theological Seminary. Historical essays on the beginning of Christianity and its distribution in Siberia (1804-1915), Op.1. D.3. L.20.

Complete collection of laws of the Russian Empire (1830). In 45 volumes, Saint Petersburg, 3, No. 4962. 
itself extremely vividly. The newly-baptized, despite the decrees of 1719 and $1724-$ "not to collect" the poll tax from the Siberian Yasak people, were included in the census of 1725 in the Siberian province, they also did not receive any privileges for the payment of Yasak (Fedorov, 1979: 84-85).

In the first quarter of the $18^{\text {th }}$ century, Christianization of the indigenous peoples of Siberia acquired the character of state policy; it was implemented in close interrelation between secular and spiritual authorities. Orthodox missionaries received the exclusive right to spread Christianity, but their activities were strictly regulated.

In the second quarter of the $18^{\text {th }}$ century, there was a decline in missionary activity, despite the permission for the priests to visit "the newly-baptized with the religious rites to see if they did not do trade $e^{1}$." One of the reasons for the decline in the pace of Christianization was the change in methods: refusal of violent methods and development of stimulating ones. In 1732, 1733, 1740, there were decrees on "non-offending the newly-baptized", "granting benefits in tax payment". Everyone who received baptism was given money gifts from 50 kopecks to one and a half roubles, a piece of cloth, a shirt, boots or a hat ${ }^{2}$.

Formally, the success of the missionary activity of the Orthodox Church was enormous. Missionaries sometimes converted tens of thousands of people to Orthodoxy in quite a short time. However, most of the newly-baptized took Orthodoxy fictitiously, as a result of violent methods of Christianization, or for the sake of benefits (privileges, gifts). Sometimes the same people were baptized several times to receive gifts, thereby officially increasing the total number of baptized people. In the second half of the $18^{\text {th }}$ century, there was a decline in the missionary activity of the Orthodox Church; first of all, it was due, to the policy of tolerance of Catherine the Great.

Expeditions, going on a long journey, received special instructions where they were reminded about the Orthodox mission and were not allowed to carry out baptism without the voluntary consent of the newly converted. One of these instructions written to the teacher of the Slavic-Greek-Latin Academy Filevsky, developed in 1733 by Inokentiy Nerunovych, stated: "In a sermon of the Word of God, if possible, firstly use the language of the people to whom it is addressed." He proposed to open a school in Irkutsk, and admit "those of the unfaithful peoples" at their will; to free from the 
Yasak for 10 years; to give out crosses, canvas, cloth, bread'. Inokentiy's proposals were not accepted and, as noted above, missionary activity as a whole turned sour.

The practice of attracting people to Christianity by means of various privileges continued in Elizabethan times as well. For accepting Orthodoxy people received a reward: the newly-baptized over 15 years old - 10 roubles; from 10 to 15 years old - 5 roubles; less than 10 years old - clothes, shoes ${ }^{2}$. The decree of March 11, 1741 freed the newly-baptized from the death penalty for murder and other grave crimes. Tax privileges were preserved (September 28, 1743) ${ }^{3}$, from 1760 the tax arrears accumulated before the baptism were forgiven ${ }^{4}$, free-quarter and other state duties were abolished ${ }^{5}$. In 1754 , it was forbidden to fine the newly-baptized for the nonattendance of confessions ${ }^{6}$. On May 31, 1760, the government ordered "not to oppress the newly-baptized, not to demand them in the courts of law on cases that concern them, without contact with a certain official, to satisfy their claims to Russian and unbaptized people with fairness and to consider cases of their mutual claims by people elected from their own class.".

But the success of the mission was formal; it required not only baptism, but also the establishment of the numerous nationalities of the eastern peripheries of the Russian Empire in Christianity. The formal character of baptism was noted by historians of the $18^{\text {th }}$ century. V.N. Tatishchev wrote: “...and although they carry out baptism, for example Philotheus the Archbishop of Siberia, but when we take a look, we see that he only bought them, put on white shirts and baptized them... and just like the baptizers returned to their homes, the baptized soon all forgot and did not know they have faith" (Tatishchev, 1979: 103-104).

In 1763, the term "freedom of conscience" could be heard for the first time in Russia. It implied the right of a person to freely profess a particular faith, or not to profess any faith at all, to perform religious rites without restriction. The Christian mission among non-Russian peoples of the Russian Empire began to be guided by the principles of religious tolerance. In historical literature, "religious tolerance" is defined as liberal attitude towards religion, but in the $18^{\text {th }}$ century it had a different meaning. Russian non-Orthodox peoples took the new principles as an opportunity

\footnotetext{
Instruction to the missionary Filevsky (1865). Irkutsk diocesan journal. Irkutsk, 23, p. 349-351.

Complete collection of laws of the Russian Empire (1830). In 45 volumes, Saint Petersburg. No. 8236.

Ibid., 9, No. 8349, 8792.

4 State Budgetary Institution of the Tyumen Region "State Archives in Tobolsk": F. 156: Tobolsk Theological Seminary. V. 1, F. 156, Op. 1. 1760. D. 127. L. 19.

Complete collection of laws of the Russian Empire (1830). In 45 volumes, Saint Petersburg, 12, No. 9210.

6 State Budgetary Institution of the Tyumen Region "State Archives in Tobolsk": F. 156: Tobolsk Theological Seminary. V. 1, F. 156, Op. 1. 1754. D. 10. L. 3.

7 Complete collection of laws of the Russian Empire (1830). In 45 volumes, Saint Petersburg, 9, No. 5050.
} 
to confess their faith without restrictions. The Russian Orthodox Church interpreted religious tolerance as an opportunity for unhindered acceptance of Orthodoxy by the non-Orthodox (Islaev, 2005: 9).

The liberal reforms of Catherine the Great in the confessional field made it possible to begin the legislative establishment of religious tolerance. The Empress's opinion on the religious question was reflected in the Model Order of the Legislative Commission: "In such a great state spreading its ownership over so many different nations, a vice, prohibition or denial of their faiths was a very bad thing for the safety and security of its citizens... Persecution against human minds is annoying, and permission to believe by people's own law softens the cruellest hearts and diverts them from... stubbornness, thus suppressing their arguments that are horrid to the silence of the state and the unity of citizens" (Kamensky, 1992: 175).

To introduce the new principles of religious policy, a special commission consisting of members of the Synod under the chairmanship of Novgorod Metropolitan Dmitriy (Sechenov) developed instructions to the bishops and preachers. The rules regulated the whole process of missionary activity and the missionaries' duties: before they are sent they must receive instructions from the bishop; the bishop is obliged to inform about the missionaries of civil authority, and, on the contrary, the missionaries inform the bishop their about activities consulting on all emerging issues. It was recommended that the sermon should be performed only in the locality closest to the episcopal residence in the Russian language, but the Symbol of Faith, the Decalogue and the Lord's Prayer, with a brief explanation, should be presented to the gentiles using the ,intelligible” language. Certain measures were proposed to train missionaries and parish pastors in local seminaries. In the opinion of the authors, a missionary must be distinguished by gospel meekness and love for "the gentiles and the newly-baptized." Larceny, extortion and threats were condemned, and a "strict penalty with oppression" was called "violence of conscience", because it "only embitters a pagan and the Mohammedan'."

Also, "Guidance for the conversion of the non-Orthodox" and the Oath for missionaries were developed. From that moment, parish priests were forbidden to travel with missions to baptize people without permission. The documents were approved by the Empress on January 8, 1769, and in the same year new rules were applied in the Tobolsk diocese. Subsequently, they were supplemented taking into account the experience of missionary practice. For example, on April 3, 1788, amendment was made

State Budgetary Institution of the Tyumen Region "State Archives in Tobolsk": F. 156: Tobolsk Theological Seminary. V. 1, F. 156, Op. 1. V. 1. 1770. D. 44. 76. L. 
to the Guidance, which allowed admission of children of the newly-baptized people in seminaries so that "they would not forget their natural language, and other natural Russian pupils could borrow notions of their language through communication with them, thus they would obtain the perfect knowledge'." The Guidance with corrections and amendments was used in all dioceses of the region.

Under the rule of Paul I, missionary work was terminated by a government order; special missions were closed throughout Eastern Siberia until the second quarter of the $19^{\text {th }}$ century. The pace of Christianization declined, and cases of rejection of Orthodoxy by the newly-baptized occurred more frequently. The policy of religious tolerance continued throughout the entire $19^{\text {th }}$ century, its main goal was to organically include the multinational and multi-confessional population of the outskirts into the Russian Empire, but, unfortunately, it negated the activities of missionaries.

By the beginning of the $19^{\text {th }}$ century changes in the Siberian economy made it obvious that Siberia "can offer more than some expensive furs" and that it can become "more than forced residence for criminals and undesirable persons." Until local rulers managed to deliver the furs in the right amount, the central government left them alone, as noted by I.L. Dameshek (Dameshek, 2002: 26-27). The administrative and territorial management of the region had developed from the first quarter of the $19^{\text {th }}$ century. At the end of $19^{\text {th }}$ century, the Great Siberian way was built - the Trans-Siberian railway from Ekaterinburg to Vladivostok. Further colonization of Siberia was accompanied by an increase in the number of the Russian population, which means that the process of Russification of the indigenous peoples intensified.

Naturally, most of the higher clergy did not recognize the policy of religious tolerance, but, like the secular authorities, they understood that the missionary work needed to be changed. In the opinion of Philotheus Ornatsky, a missionary should teach the non-Russian people "loyalty to the sovereign, submissiveness to the authorities, feelings of fraternal affection for the Russians", but at the same time, introduce "the main truths of the Christian faith." He also believed that the church and the state should join forces, work together, because "at the end of the last century and the beginning of the present century, we had certain views on the missionary mission as solely the business of the church, we began to say that the interference of the state power in the matter of conversion of pagans to Christianity is unfair, since it leads to violation of the rules of religious tolerance. Such views, being carried out in relation to the non-

State Budgetary Institution of the Tyumen Region "State Archives in Tobolsk": F. 156: Tobolsk Theological Seminary. V. 1, F. 156, V. 1 1767. D. 36. L. 78. 
Russians in Siberia, have led to the fact that the successes of the Christian sermon have been suspended for a long time and are hampered at the present time ${ }^{1}$." In his opinion, another reason for the failure of the mission was the following circumstance: "The pagan-foreigners themselves want to adopt Christianity, but taking Christianity as Russian faith, they think that with the adoption of faith they must change the nomadic way of life to a settled one and change the whole structure of their life 2 ."

In the future the missionary work developed according to the following scheme: first, in the first half of the $19^{\text {th }}$ century, the General Department of Spiritual Affairs of Foreign Confession was organized. This special department in 1817 was included into the Ministry of Spiritual Affairs and Public Education, later it was renamed into the Ministry of Public Education (1824), and in 1832 was incorporated in the Ministry of Internal Affairs. In the Ministry of Internal Affairs, this department functioned as a department of spiritual foreign confession, performed functions of information and control, including non-Christian religions, paganism. The documents of this department were distributed between the spiritual consistory and the provincial chancellery.

In addition to the Department of the Ministry of Internal Affairs, the Russian Bible Society was founded in 1812. This society was intended to spread the Holy Scriptures among foreigners and non-Russians. The representatives of the Russian Bible Society translated church books into the languages of non-Russian peoples of Russia. The first translations of the foundations of Christianity into the languages of the peoples of Siberia began in $1803^{3}$. From 1814 to 1824 the translations of the New Testament were published in the Chuvash, Tatar, Mordovian, Zyryan, Votian and Karelian languages.

Secondly, new forms of missionary work appeared and developed, for example, they began to establish field churches, the missionaries could conduct worship services in remote places. For the missionaries, the camps were opened: in 1815 a camp for missionaries was opened in the Irkutsk diocese, in 1824 in the Archangelsk diocese, there were four missions in general in Russia: the Ossetian in the Caucasus, the Samoyed in the Arkhangelsk Province, the Beijing and in Siberia ${ }^{4}$. The presence of camps greatly facilitated the life and work of the missionaries locally.

Yeniseisk diocesan journal (1890). Krasnoyarsk, No. 15, p. 242.

Idid., p. 246.

Decree of 1803 “About translations into foreign languages of the Apostles' Creed, Decalogue, church prayers and catechesis", Decree of 1804 "On the use of a foreign language in teaching children of non-Russians to read and write at the instruction of non-Russians in the church, and about the appointment of persons who speak foreign languages to the clergymen of foreign churches".

4 Materials on the history of the Orthodox church during the reign of Nicolaus I (1902). Edited by N.F. Dubrovin: Saint Petersburg, Books 1, 2. p. 6. 
It should be mentioned that the Orthodox mission was the task of parish priests, they were responsible for the rapprochement of non-Russians with the Russian population, they were supposed to improve their attitude towards Orthodoxy and the Orthodox clergy. In addition to camps establishment, priests were trained for work in Siberia. They studied the indigenous languages of Siberia, could teach at school, making school education more affordable. In some communities, schools were opened with the teaching of their native language. In 1825, the need to translate the Holy Scripture into the languages of all the peoples of the Russian Empire was formalized and an appropriate decree was issued ${ }^{1}$. However, it is noteworthy that in the first quarter of the $19^{\text {th }}$ century not too many special documents regulating the confessional policy were issued: the decree of 1803 on the prevention of the secession from Orthodoxy and the decree of January 10, 1810 on the punishment for non-attendance of confession.

"The Charter on the management of non-Russians" allowed to change the management system in Siberia in 1822. It both confirmed and specified the principle of religious tolerance. This happened with the active participation of the activists of the Bible Society, first of all, M.M. Speransky. In $\S 286$ it was said that "non-Christians have the freedom to perform the worship according to their laws and customs", Article 98 permitted to organize "a decent place for praying" in the distance from churches. Chapter $11 \S 291$ forbade fines and penalties against the newly baptized, "if they, professing the Christian faith, turn out to be ignorant in relation to church rites. Suggestions and beliefs are some decent measures in this case. "The Charter permitted marriages between baptized and unbaptized, as well as pagan and Christian "rites peculiar to every religion". Marriages between relatives committed before the adoption of Christianity, were not subject to annulment ${ }^{2}$.

M.M. Speransky's reforms allowed on the legal basis to include missionary work into state interests and to designate its place in the national imperial policy. The reform was based on the idea of inducing indigenous peoples to perceive the Russian culture, ways of doing business, organizing everyday life, etc. It was supposed that this should be done by missionaries who need to be sent to the remotest corners of the empire to conduct there not only religious but also educational activities.

Complete collection of laws of the Orthodox Department of the Russian Empire (1869-1905). Saint Petersburg, 9 (97), p. 119.

2 Idid., 9 (61), 75. 
Therefore, the reforms of the end of the reign of Alexander I had a new focus in relation to the non-Orthodox population: Russification through the culture of the Russian population with simultaneous gradual Christianization (Sofronov, 2007: 138144).

The rise of missionary work begins during the reign of Nicholas I (1825-1855), whose domestic policy relied on the so-called "triad" of S.S. Uvarov: Orthodoxy, autocracy, nationality. In connection with the tasks of educating loyal feelings among the population of the country, measures were taken to strengthen the role of the ROC in society. This means, first of all, that missionary work in Siberia once again became a priority in the policy of the state. In 1833 Nicholas I directly demanded to strengthen missionary work in Eastern Siberia. In his opinion, the essence of Christianization of the indigenous peoples of Siberia was the realization of the ideas proposed by the government of Alexander I: Russification and activation of Christianization. The policy of Russification at this stage was characterized by administrative centralization, destruction of local privileges and national differences. The non-Russian peoples of the Russian Empire needed to be inspired by the sense of belonging to Russia, to do so through the habit of using the Russian language and conversion to the Orthodox faith.

The emperor demanded that the ROC took effective measures in the implementation of this policy, and the Most Holy Synod proceeded to draft a legal framework for missionary activities. The preparation of the project was entrusted to the Kazan Archbishop Filaret Amfiteatrov and Tobolsk Bishop Evgeny Kazantsev. They developed special "Rules" of missionary work, which emphasized that the number of baptized people is not as important as their thorough preparation for baptism. Filaret recommended to start from worshiping and, based thereon, explain the dogmas, but the main thing, he said, was the constant guidance of the baptized ${ }^{1}$

In the late $1820 \mathrm{~s}$, it became apparent that parish priests do not cope with burdensome missionary duties. This led to the return of special missions in lands inhabited by indigenous peoples, led by trained qualified preachers. But there were no special Orthodox missions in the Khakass lands during this period.

In the 30 s of the $19^{\text {th }}$ century the Altai, Obdorsk and other missions were opened, where the educational principles of missionary work were introduced. The Obdorsk mission lasted eight months, christened only 17 people $^{2}$, it was reopened only in 1854

1 Complete collection of laws of the Orthodox Department of the Russian Empire (1869-1905). Saint Petersburg, 9 (154), 211-212.

2 State Budgetary Institution "Russian State Historical Archives": F. 797: Chancellery of the Most Holy Synod, Op. 96. D. 45. L. 16. 
and existed until the establishment of the Soviet power in the north of Western Siberia (Sofronov, 2007: 38). The Kondinsky mission was established in 1836 on the basis of a monastery, but missionary work was started only in 1844. Already in 1860 its activity was found unsatisfactory, it existed as a mission until 1891, when it was transformed into a female missionary community (Sofronov, 2007: 38). The tasks of the Kondinsky and Surgut missions in the $19^{\text {th }}$ century did not focus on baptizing the indigenous peoples, but strengthening them in the Orthodox faith. The Obdorsk mission had its own structure (camp, prayer houses, field churches, later women communities and a missionary brotherhood), which allowed missionary work among the pagans of the vast Berezovsky region, covering its remote lands with church propaganda.

In August 1830, the Altai spiritual mission was established in the villages of Ulale and Maima, two large missionary camps were opened there. The head of the mission Makarii (Glukharev) became the ideologist of the new policy of Christianization of the indigenous peoples of Siberia. In his opinion, the ideal missionary should be both a doctor and a farmer. In 1839, Makarii outlined his system of training missionaries in his work "Thoughts on the ways to successfully spread the Christian faith in the Russian state" (published in 1894). He created the Altai script and translated some liturgical books and the New Testament into the Altai language. The Altai mission represented one or two huts in which there were a field church and the missionary's home. In the middle of the $19^{\text {th }}$ century, a clearly expressed structure of the missionary camp was formed in Altai with a temple, a school and a home of the missionary in its centre. Similar camps became the basis for the missionary villages of the newly baptized (Kreidun, 2006: 15-24). Seminaries began to teach "foreign" languages. In the report on the Altai spiritual mission it was noted that baptized "boys and girls are more eager to study Russian diplomacy than in the villages of indigenous people"1. Makarii's ideas began to take root only in the 1860s. At that time he visited the Khakass lands, singling out a talented Altaic preacher Semen Chesmochakov. But just at that time, in the 60s of the $19^{\text {th }}$ century the attitude of the higher clergy and civil authorities towards missions had deteriorated.

The work of the Orthodox missionaries in Siberia among non-Russians became educational, schools were opened for children of the non-Russian population, textbooks in their native language were published, and foreigners who spoke Russian became the first teachers. The decree of 1804 "On the use of a foreign language in teaching children

State Budgetary Institution "Russian State Historical Archives”: F. 796: Chancellery of the Synod, Op. 442. D. 77. L. 5. 
of non-Russians to read and write at the instruction of non-Russians in the church, and about the appointment of persons who speak foreign languages to the clergymen of foreign churches" was intended to facilitate the educational work of missionaries, but it was widely disseminated only in the 30 s.

By 1850 the hierarchy of the missionary work had developed, according to it, the leadership was exercised by the bishop, diocesan missionaries who worked with nonRussians and struggled with schismatics; the diocese was divided into districts, and district missionaries stood at the head of the district.

In 1842, a decree was issued to impose penalties for apostasy from the Orthodox faith. The appearance of this decree was preceded by multiple reports from the field that in the dioceses of Siberia the newly baptized continued to perform their pagan rituals even after baptism. Responsibility for the implementation of this decree was assigned to the Minister of the Internal affairs, he ordered the governors "to monitor the prohibition for the newly baptized to perform pagan rituals". If, however, the reports on the performance of pagan rituals continue to arrive, then the diocese had to verify for itself whether they were true. City police officers were ordered to check if "all newly baptized go to church indelibly, especially on Sunday and solemn days, as well as each year confess and receive the Sacrament and so that it is possible to go away from wrong customs". All orthodox "Russian people born and educated in the Orthodox faith, who live with newly baptized in some villages" had to follow "for the newly baptized apostates - admonish, if it does not help, then inform the parish priests". The same decree demanded that the priests, if they did not "succeed in turning the newly baptized away from pagan rites", appealed to the secular authorities for the execution of punishment. The decree recommended: "... where pagan rites are performed by baptized non-Russians, the priests come there at the time when they usually happen to reject them from superstitious actions, affirming in piety by brief instructions or committing, without demanding payment, any prayers in substitution of a pagan rite for the sake of observation and general agreement with them. In the case of stubbornness and superstition, measures must be taken, the aggravation should be intensified appealing to the zemstvo court or volost administration". ${ }^{1}$

These and other factors proved that the missionary system in general had become inefficient. As a result of purposeful Christianization, most pagans introduced into the

Complete collection of laws of the Russian Empire (1830). In 45 volumes, Saint Petersburg, 7, D. 96, 35 p. 
Orthodox faith according to the witness of the Tobolsk archbishop Evgenii Kazantsev "continue to pray to their gods and do not know how to cross themselves".

Another important task of representatives of the clergy working in Siberia was a constant energetic, intensive work with indigenous people, in order to keep them in the Orthodox faith. This task required significant changes in the structure of missionary work. First of all, according to the clergy, it was necessary to return the missionaries: "This important duty can be fulfilled only by missionaries - people not involved in any special secular affairs". It was proposed "to establish an order or a monastery in the very middle of these ignorant peoples and determine the number of monks in it and this holy brotherhood could freely replace the preachers". The success of all activities is possible only if "from the civil side, the superiors have care for their welfare", converts to Orthodoxy must get rid of their shortcomings, such as "laziness and idleness, otherwise all proposed measures will aggravate different prejudices and vices that they have" 2 .

In the $60-70 \mathrm{~s}$ of the $19^{\text {th }}$ century the Russian Empire changed the national policy, which was due to the processes of modernization and the rise of national movements. The new national policy was aimed at Russification, homogenization of the Russian society, cultural unification, and the means of implementing this policy was confessional politics. This led to the activation of the activities of the Orthodox "non-Russian" mission, regulation of its activities by the government and strengthening of control. Enlightenment policy, i.e. education of non-Russian peoples of the Russian Empire, becomes more rational. As L.V. Dameshek notes, in the second half of the $19^{\text {th }}$ century the transition from "feudal-serfdom methods of Christianization to bourgeois ones" was the next stage" (Dameshek, 1986: 163).

By 1862 , it was decided to establish a Special presence to find ways to improve the way of life of the clergy. Its chairman was the St. Petersburg Metropolitan, and its members were ministers, the chief prosecutor, all members of the Most Holy Synod, the director of the Synodal Spiritual and Educational Board and the State Secretary of the State Council.

Since the end of the $19^{\text {th }}$ century, since 1863 , the domestic policy of the Russian Empire turned towards the cultural and linguistic uniformity of the outlying areas of the state and their administrative association. For non-Russian ethnic groups, this meant, first of all, the more aggressive behaviour of the authorities with respect to

Russian Orthodoxy: milestones of history (1989). Edited by A.I. Klibanova, Moscow, Politizdat, p. 337.

Archival agency of the Krasnoyarsk Krai: F. 658: Achinsk Spiritual Board, Op. 1, D. 96, L. 13-14. 
the cultural and domestic characteristics of these ethnic groups. At this time, the missionaries changed tactics, they tried to raise the authority of their church, change the attitude of the people towards the clergy, bring non-Russians closer to the Russians. In seminaries of non-central dioceses, for example, in Irkutsk, they began to teach pupils local languages. In Kazan, liturgical books were translated into the Kalmyk and Tatar languages.

Alexander III was more conservative than Alexander II. He believed that Christianization of non-Russian peoples should lead to Russification. Similar ideas were expressed by some representatives of the clergy. For example, Archbishop Veniamin of Irkutsk expressed the idea that Orthodoxy should fight against another faith, against a different nationality, against the past ordinary life of "non-Russians". The missionary was "to convince them in the superiority of the Russian national life, so they become Russians not only by faith, but also by nationality. This change in their eyes is such a condition, without which one cannot be a real Christian" ${ }^{1}$. There was no such a task set before the missionaries before, but at the beginning of the $20^{\text {th }}$ century, strengthening of paganism, which, evidently, was one of the manifestations of ethnic self-identity, led to the need to spread Orthodox Christianity locally.

By the end of the $19^{\text {th }}$ century, the system of the ROC missionary activities was changed, while the existing system did not bring any visible results. During this period, they ceased to baptize children without the consent of their parents or legal representatives, children over the age of 14 were asked to consent, it was forbidden to baptize patients in an unconscious state. Now baptism took place necessarily in the church with the local leaders or other reliable witnesses. With the change of residence, the newly baptized were given money. In addition, "if during the investigation or trial... non-Christians agreed to accept the Orthodox ... faith", the punishment was mitigated.

In 1886, when summarizing the work of the missionaries, the following recommendations were developed to improve the process of Christianization:

- firstly, it was recommended to learn the language of non-Russians; the task of the seminary's teachers was to teach their students to translate from Russian into Russian;

- secondly, it was necessary to study the faith of non-Russians, to get to know how they live;

- thirdly, books for the missionaries were to be published and distributed;

Religious education (1916). Yeniseisk eparchy news, 12, p. 24. 
- fourthly, the need to create church-parochial schools for non-Russians was recognized, the teachers to work in them were supposed to be Orthodox, graduates of special missionary courses ${ }^{1}$.

It should be noted that early in the $19^{\text {th }}$ century there were missionaries who tried to use only the belief in the advantages of Orthodoxy in their activity, but most preachers preferred to use monetary incentives: “... those who wanted to get baptized, were given a robe, a shirt and 3 roubles". These incentives often worked, especially since it was not necessary to teach prayers and commandments. The missionary baptized and told the new convert "You are now Orthodox, you should cross yourself whenever you see a church".

Another effective and widespread method of conversion to Orthodoxy was the royal persons on the territory of the Russian Empire. For example, in 1891, then the crown prince, the son of Alexander II, the future Nicholas II made a trip to the Transbaikal region, visited the Irkutsk and Yeniseisk provinces. During this trip a large number of autochthons turned to the new faith and received the name "Nicholas" at the baptism.

As it has been repeatedly mentioned, the knowledge of the language, psychology, peculiarities of life and culture of the population, among which the missionary worked, were of special significance (Fendel, 2006: 44-50). Moreover, the missionaries were supposed to be able to provide medical assistance, as the health care system in Siberia was not developed. Since the end of the $19^{\text {th }}$ century. when greater importance was paid to medical knowledge when teaching the missionaries, they were also given a first aid $\mathrm{kit}^{2}$. Age was also important for the missionary, as in the traditional society the elderly people were more respected, so the indigenous peoples of Siberia trusted a man of mature age more.

At the turn of the $19^{\text {th }}-20^{\text {th }}$ centuries, the educational activity of the clergy became more important, textbooks for missionaries of Siberia were published, books were translated into the languages of Siberian peoples. In Moscow in 1887, the first AllRussian missionary congress was organized, during which a "new" missionary system was developed. The struggle against sectarianism and the Old Believers came to the forefront. Missionary work among the non-Russian peoples of Russia, and, therefore, in Siberia, declined. The missionaries conducted educational work, continued to travel

1 Decree of the Bishops' Meeting in Kiev on schisms and sects, and measures to weaken the schismatic propaganda (1886). Yeniseisk eparchy news, 13, p. 184.

2 Christianity and Lamaism among the indigenous population of Siberia (second half of the $19^{\text {th }}-20^{\text {th }}$ centuries) (1979). Leningrad, Nauka, p. 8. 
around the country, held congresses, published magazines and books. For example, by 1899 the ROC were publishing 86 newspapers and magazines (Bonch-Bruevich, 1975: 214). Nevertheless, despite all efforts, by the beginning of the $20^{\text {th }}$ century the missionary activity of the ROC started to decline.

\section{Conclusion}

The analysis of the ROC's missionary work and state religious policy allows us to draw the following conclusions. Since the beginning of the $17^{\text {th }}$ century, the religious policy towards the indigenous peoples of Siberia was part of the state policy that tried to develop one rule for all spheres of life and for all territories. Over time, the spheres of activity of secular and spiritual authorities had been divided, secular authorities continued to deal with economic and geopolitical issues, and spiritual with departmental ones. Over time, this allowed to replace the violent methods of Christianization with the policy of religious tolerance, making the Russian Orthodox Church a monopoly. Moreover, the system of missionary work, principles of work and methods of control were developed. Thus, the process of Christianization of Siberia can be divided into six periods:

- the first period, the $17^{\text {th }}$ century: at that time the first settlers, fishers and Cossacks came to Siberia, through them acquaintance with Christianity was started;

- the $17^{\text {th }}$ century, until 1764 was characterized by the fact that the baptism of the peoples inhabiting Siberia did not occur systematically, violent methods were often used, but during this period the status of "newly baptized" was officially fixed, missionary institutions were created, instructions for missionaries were developed;

- at the end of the $18^{\text {th }}$ century, diocesan missionary work was started, the principle of religious tolerance was proclaimed in public policy, funding was allocated for the construction of churches, but the educational methods of turning people to the new faith were still in the background;

- in the next period of Christianization, the fourth one, at the beginning of the $19^{\text {th }}$ century, the religious policy of the state again changed towards non-religious methods, refusal of mass baptisms was practiced, field churches and missions appeared;

- by the middle of the $19^{\text {th }}$ century, the goals of Christianization changed, the state strictly controlled the church, demanding to fight against any manifestation of other religions;

- during the last, sixth period, the baptism of non-Russian peoples of the Russian Empire was formally completed, the state turned to the policy of assimilation and 
Russification; the policy of Russification was to bind the indigenous peoples of Siberia to Russia, but in reality this led to ethnic consolidation and counteraction to Christianity.

The historical destiny of Russia has resulted in multinationality and multiconfessionality, in this situation turning the indigenous peoples of Siberia to Orthodoxy played a huge role in solving economic and political issues of the state, after two hundred years that were required for the settlement of Siberia, the state policy changed from violence to tolerance.

What does the concept of the diocesan missionary department of the new time offer us? First of all, the above-mentioned concept implies not so much missionary work, but the formation of the mission system, training of personnel, creation of a volunteer mission. At first glance it seems that the creators of the concept really took into account the historical experience of the mission of the Russian Orthodox Church and its prospects. The internal mission has been chosen as the priority direction, but it is not aimed at the Old Believers and sectarians, but at those who have not been converted to Orthodoxy, being a representative of the people traditionally professing the Orthodox religion. The willingness to build a dialogue with representatives of sects and neo-pagans (to save them from pseudoreligious faith) evokes special respect. Undoubtedly, the most important idea that has been taken into account in the preparation of the concept is interaction with the authorities, because a purposeful state policy can give a quick result. Interaction with the state is supposed in the sphere of prevention of religious extremism and interconfessional conflicts. The ROC missionaries try to prevent actions and statements with signs of extremism and xenophobia. Thus, new missionaries from the ROC only postulated the forms and methods of work of their predecessors. Closer examination makes it obvious that there will be no global changes in the missionary activities of the ROC. Let us hope that, as many years ago, in fact much will depend on the personality of the missionary.

\section{References}

Allievi, S. (2014). Immigration, religious diversity and recognition of differences: the Italian way to multiculturalism. In Identities, 21 (6), 724-737.

Andrievich, V.K. (1886). Istoricheskii ocherk Sibiri po dannym, predostavliaemym Polnym sobraniem zakonov [A historical sketch of Siberia according to the data submitted by the General Assembly of Laws]. Irkutsk, 353 p. 
Bloom, P.B.N., Arikan, G., Courtemanche, M. (2015). Religious social identity, religious belief, and anti-immigration sentiment. In American Political Science Review, 109 (2), 203-221.

Bohman, A., Hjerm, M. (2014). How the religious context affects the relationship between religiosity and attitudes towards immigration. In Ethnic and Racial Studies, 37 (6), 937-957.

Bonch-Bruevich, V.A. (1975). Sily russkogo klerikalisma [Forces of Russian clericalism], In Religiia I tserkov'v istirii Rossii [Religion and Church in the History of Russia], $255 \mathrm{p}$.

Brown, R.K., Brown, R.E. (2017). Race, religion, and immigration policy attitudes. In Race and Social Problems, 9 (1), 4-18.

Dameshek, I.L. (2002). Sibir'v sisteme imperskogo regionalizma (komparativnoe issledovanie okrainnoi politiki Rossii v pervoi polovine 19 veka) [Siberia in the system of imperial regionalism (a comparative study of the marginal policy of Russia in the first half of the nineteenth century)]. Irkutsk, $165 \mathrm{p}$.

Dameshek, L.M. (1986). Vnutrenniaia politika tsarisma i narody Sibiri. XIXnachalo XX vekov [The internal policy of tsarism and the nations of Siberia. $19^{\text {th }}$ early $20^{\text {th }}$ centuries]. Irkutsk, $165 \mathrm{p}$.

Fedorov, M.M. (1979). Pravovoe pologheniie narodov Vostochnoi Sibiri (XVII nachalo XIX vekov) [The legal status of the nations of Eastern Siberia $\left(17^{\text {th }}-\right.$ early $19^{\text {th }}$ century)], Moskva, 364 p.

Fendel', E.R. (2006). Nachal'nyi etap missionerskoi deiatel'nosti Russkoi Pravoslavnoi tserkvi v Sibiri [The start stage of the missionary of the Russian Orthodox Church in Siberia], In Istoriia Sibiri 1583-2006. Problemy i perspektivy: sbornik materialov regional'noi molodeghnoi nauchnoi konferentsii [History of Siberia 15862006. Problems and prospects: a collection of materials of the regional youth scientific conference], Novosibirsk, 280 p.

Fox, J., Akbaba, Y. (2015). Securitization of Islam and religious discrimination: Religious minorities in Western democracies, 1990-2008. In Comparative European Politics, 13 (2), 175-197.

Islaev, F.G. (2005). Religioznaia politika Rossiiskogo gosudarstva i ee realizatsiia $v$ Volgo-Uralskom regione (XVIII vek) [The religious policy of the Russian state and its implementation in the Volga-Ural region (18 th century)], Kazan', $42 \mathrm{p}$.

Kamenskii, A.B. (1992). Pod seniiu Ekateriny [Under the canopy of Catherine], Sankt-Petersburg, Lenizdat, 448 p. 
Kovaliashkina, E.P. (2005). «Inirodcheskii vopros» v Sibiri: Kontseptsii gosudarstvennoi politiki i oblastnicheskaia mysl' ["Mixed ethnic question" in Siberia: the Concepts of State Policy and local thought], Tomsk, TGU, $326 \mathrm{p}$.

Kreidun, Iu.A.(ierei Georgii) [priest Georgii] (2006). O printsipakh territorial'nogo obustroistva Altaiskoi dukhovnoi missii [About the principles of territorial development of the Altai orthodox mission], In Makar'evskie chteniia: materialy 4-oi meghdunarodnoi konferentsii (21-22 noiabria 2006 goda) [Makaryevsky readings: materials of the fourth international conference (November 21-22, 2006], GornoAltaisk, PIO GAGU, 15-25 pp.

Maliepaard, M., Lubbers, M. (2013). Parental religious transmission after migration: The case of Dutch Muslims. In Journal of Ethnic and Migration Studies, 39 (3), 425-442.

Mavliutova, G.Sh. (2001). Missionerskaia deiatel'nost' Russkoi pravoslavnoi tserkvi v Severo-Zapadnoi Sibiri (XIX - nachalo XX veka) [Missionary activity of the Russian Orthodox Church in North-West Siberia (19 ${ }^{\text {th }}$ - early $20^{\text {th }}$ centurie)]. Tiumen', TiumenGU, $177 \mathrm{p}$.

Nikonov, A.B. (1989). Kriticheskii analiz missionerskoi deiatel'nosti Russkoi pravoslavnoi tserkvi (1721-1917) [Critical analysis of the missionary activity of the Russian Orthodox Church (1721-1917)]. Leningrad, 23p.

Sanchez, M., Dillon, F. R., Concha, M., \& De La Rosa, M. (2015). The impact of religious coping on the acculturative stress and alcohol use of recent Latino immigrants. In Journal of religion and health, 54(6), 1986-2004.

Sofronov, V.Iu. (2007). Gosudarstvennoe zakonodatel'stvo Rossii po konfessional'nym voprosam i pravoslavnoe missionerstvo v kontse XVII - nachale XX vekov [State legislation of Russia on confessional politics and Orthodox missionary in the late $17^{\text {th }}$ - early $20^{\text {th }}$ century], In Izvestiia Altaiskogo gosudarstvennogo universiteta. Istoriia. [News of the Altai State University. History], 4, 138-144.

Sofronov, V.Iu. (2007). Missionerskaia deiatel'nost' russkoi pravoslavnoi tserkvi v Zapadnoi Sibiri b kontse XVII - nachale XX vekov [Missionary activity of the Russian Orthodox Church in Western Siberia in the late 17 th - early $20^{\text {th }}$ centuries], Barnaul, $52 \mathrm{p}$.

Stump, R.W. (1984). Regional migration and religious commitment in the United States. In Journal for the Scientific Study of Religion, 23 (3), 292-303.

Tatishchev, B.N. (1979). Razgovor dvukh priiatelei o pol'ze nauki i uchilishchakh [The conversation of two friends about the benefits of science and colleges], In Izbrannye proizvedeniia [Selected works], Leningrad, Nauka, $171 \mathrm{p}$. 
The concept of the eparchial missionary (2018). Available at: http://порталмиссия.pф/blog/2018/05/14/концепция-деятельности-епархиально-2/ (accessed 23 May 2018)

\title{
Contractions
}

1. The State Archives in Tobolsk: State Budgetary Institution of the Tyumen Region "The State Archives in Tobolsk".

2. FBI "Russian State Historical Archive": Federal Budgetary Institution "Russian State Historical Archive".

\section{Религиозная миграция: к вопросу об истории миссионерства в Сибири}

\author{
Н.Я. Артамонова, В.Н. Асочакова, С.С. Чистанова \\ Хакасский государственный университет \\ им. Н.Ф. Катанова \\ Республика Хакасия, 655017, Абакан, ул. Ленина, 90
}

В статье представлен анализ миссионерства как одной из форм религиозной миграции. Заселение Сибири русскими было важнейтей геополитической и экономической задачей российского правительства, в этом прочессе христианизачия коренных народов приобрела особое значение. С XVII до XX века менялась государственная политика в отношении Сибири, а вместе с ней формы и методы распространения православия среди народов, населявших ее. Авторы выделяют шесть этапов в государственной политике христианизаиии, от первичного знакомства с православной верой до перехода $\kappa$ политике русификации.

Каждый сибирский регион в составе России проходил несколько этапов: собственно присоединение, постепенная инкорпорация, ассимиляция. Эти процессы имели региональные особенности и проходили асинхронно. За два века деятельности миссионеров в Сибири насильственные методы христианизации сменились тактикой толерантности и просвещения при сохранении монополии русской православной иеркви. К сожалению, современная конщепџия деятельности епархиального миссионерского отдела показывает, что русская православная церковь не учла исторический опыт миссионеров прошлого.

Ключевые слова: миссионерство, религиозная мигращия, заселение Сибири, православие, христианизащия.

Исследование выполнено при финансовой поддержке РФФИ и Республики Хакасия в рамках научного проекта № 18-49-190002.

Научная специиальность: 46.06.01 - исторические науки и археология. 